\title{
KONTEKSTUALISASI HADIS TENTANG TRANSPLANTASI
}

\section{Lailatu Rohmah}

Universitas Islam Negeri Sunan Kalijaga Yogyakarta Lailatu84@gmail.com

\begin{abstract}
Organtransplantationasamedicaltechniqueisanewimprovement and discovery in the world of modern medicine. For example, the first successfully heart Transplantation was carried out in 1967. Until now many organs or tissues can be transplanted, including skin, cornea, bones, blood vessels, kidneys, heart, liver, lungs, and pancreas. While in the review of Islamic law, transplantation is a contemporary issue, and there are no texts in the Qur'an and Hadith that explicitly mentioning transplantation.

Because of its increasing widespread of the organ transplants, it is regarded obligatory to study further in the Islamic perspective or Hadith on organ transplants. In this article, the author analyzes the Hadith relating to the transplants, then relates to the social context and various opinions of the scholars about organ transplants.
\end{abstract}

Keywords: Contextualization Hadith, Transplantation 


\section{Abstrak}

Transplantasi organ sebagai teknik pengobatan merupakan kemajuan dan temuan baru dalam dunia kedokteran modern. Misalnya, Transplantasi jantung pertama kali sukses dilakukan tahun 1967. Hingga kini sudah banyak organ atau jaringan yang dapat ditransplantasikan, antara lain kulit, kornea, tulang, pembuluh darah, ginjal, jantung, hati, paru, dan pankreas. Sementara dalam tinjauan hukum Islam transplantasi ini merupakan masalah kontemporer, dan tidak ada nash alQur'an dan hadis yang secara eksplisit menyebutkan tentang transplantasi tersebut.

Karena semakin maraknya transplantasi organ ini, maka dipandang perlu dikaji lebih jauh dalam perspektif Islam tentang transplantasi organ tersebut. Dalam artikel ini, penulis mengkaji hadis yang berkaitan dengan transplantasi, kemudian dikaitkan dengan konteks sosial serta berbagai pendapat ulama tentang transplantasi organ tubuh.

Kata Kunci: Kontekstualisasi, Hadis, Transplantasi 


\section{A. PENDAHULUAN}

$\mathrm{K}$

emajuan ilmu pengetahuan dan teknologi telah merambah ke seluruh aspek kehidupan manusia. Kemajuan ilmu manfaat bagi manusia, di antaranya untuk mengatasi berbagai problem yang dihadapinya. Salah satu bidang kemajuan ilmu pengetahuan dan teknologi adalah bidang kedokteran yang memunculkan berbagai macam bioteknologi. Tidak bisa kita pungkiri adanya terobosan baru dalam bioteknologi, seperti adanya kloning, eutanasia, bayi tabung, dan transplantasi organ tubuh.

Islam pada dasarnya telah meletakkan kaidah-kaidah kesehatan secara luas, namun ia tidak berbicara tentang pengobatan secara rinci. Dalam al-Qur'an sendiri tidak akan didapatkan dosis obat tertentu untuk suatu penyakit tertentu pula. Islam memotivasi untuk menghormati medis dan dokter, serta melakukan penelitian-penelitian kedokteran. Banyak orang yang bertanya kepada Rasul tentang masalah ini, dan bahwasannya apabila beliau sakit, beliau tidak mengobati dirinya sendiri, tetapi memanggil dokter untuk mengobatinya. Allah dan Rasul-Nya tidak membatasi umat pada umumnya dengan sistem pengobatan tertentu, agar dapat berkembang dan melakukan penelitian selaras dengan arus modernisasi. ${ }^{1}$

Masyarakat Islam yang hidup sekarang ini maupun di masa mendatang, akan berhadapan dengan masalah-masalah baru yang belum pernah ada sebelumnya dalam seluruh aspek kehidupan. Karena itu, kaum muslimin dituntut untuk menyelesaikan masalah-masalah kontemporer itu secara relevan dan realistis. Banyak hasil percobaan penelitian di kalangan ilmuwan kedokteran modern yang membawa implikasi merebaknya kontroversi ketika hasil penelitian tersebut dipublikasikan. Tanggapan mendukung maupun menolak pun bermunculan, disertai dengan kekuatan dan kelemahan argumen-argumen masing-masing.

Salah satu kemajuan dalam dunia kedokteran adalah dengan

1 Ahmad Syauqi al-Fanjari, Nilai Kesehatan dalam Syariat Islam. Terj. Ahsin Wijaya dan Totok Jumantoro (Jakarta: Bumi Aksara, 1996), h 192. 
transplantasi organ tubuh. Transplantasi mulai populer di dunia kedokteran sejak pertengahan tahun 50-an. ${ }^{2}$ Transplantasi organ tubuhyang pertamakalisukses dilakukan adalah transplantasiginjal antara sepasang kembar identik. Setelah itu, transplantasi ginjal terus dikembangkan untuk memungkinkan transplantasi di luar kembar identik. Setelah mendapatkan cukup pengalaman dengan transplantasi ginjal, dunia kedokteran mulai mengembangkan transpalantasi hati, paru dan jantung.

\section{B. PEMBAHASAN}

\section{Problematika}

Transplantasi adalah pergantian organ atau jaringan tubuh yang tidak lagi berfungsi dengan organ atau jaringan sehat yang berasal dari tubuh sendiri atau orang lain. Menurut Jeff E. Zhone bahwa sejak awal abad ke-8 SM telah terjadi penggantian organ tubuh yang rusak, yakni yang dilakukan para ahli bedah Hindu yang melakukan transplantasi kulit untuk mengganti hidung yang hilang karena penyakit sifilis, perang fisik, atau hukuman atas suatu kejahatan. ${ }^{3}$

Dalam literatur hadis juga dituturkan peristiwa 'Arfajah, seorang sahabat Nabi SAW yang kehilangan hidung dalam suatu pertempuran dan diganti dengan hidung palsu dari perak. Hidung peraknya itu beberapa waktu kemudian menimbulkan bau yang tidak sedap, sehingga ia meminta nasihat Nabi, lalu beliau menganjurkan agar mengganti hidung perak itu dengan hidung palsu lain dari emas. ${ }^{4}$ Namun demikian, transplantasi suatu organ tubuh dari spesies yang sama belum pernah terjadi sampai pada tahun 1913, yaitu ketika Dr. Alexis Carrel, seorang ahli bedah dari Perancis, berhasil melakukan transplantasi ginjal seekor kucing pada kucing yang lain. Proses transplantasi

2 http://www.republika.co.id/suplemen/default.asp?mid=2. Download tanggal 17 April 2017

3 Abul Fadl Mohsin Ebrahim. Kloning, Eutanasia, Transfusi Darah, Transplantasi Organ, dan Eksperimen pada Hewan Telaah Fikih dan Bioetika Islam. Terj. Mujiburrohman (Jakarta: PT Serambi Ilmu Semesta, 2004), h. 14.

4 Ibid. 
ini berhasil dilakukan setelah ia menguasai cara penjahitan ujung-ujung pembuluh darah yang telah dipotong agar darah dapat mengalir kembali secara efisien sebagaimana sebelum dioperasi.

Transplantasi organ pertama kali pada manusia adalah pada 3 Desember 1967, Prof. Christian N. Barnard beserta tim ahli bedahnya dari Afrika Selatan berhasil melakukan pemindahan jantung dari seorang wanita bernama Denise Darvall (24 tahun), yang dinyatakan mati otak akibat kecelakaan akibat kendaraan bermotor, untuk ditransplantasikan pada tubuh seseorang bernama Louis Washkansky (54 tahun). Washkansky sanggup bertahan hidup selama 18 hari dan kemudian meninggal karena infeksi paru-paru yang mengakibatkan kurangnya oksigen yang masuk ke dalam jantung barunya itu. Kemudian pada tanggal 2 Januari 1968, Barnard melakukan transplantasi jantung pada Dr. Philip Blaiberg, yang akhirnya ia bisa kembali menjalani hidup dalam keadaan sehat seperti sediakala. ${ }^{5}$

Keberhasilan ini segera diikuti oleh pusat transplantasi jantung lainnya di berbagai belahan dunia. Meskipun hasil awal kurang memuaskan, dengan makin baiknya kriteria seleksi donor dan resipien, penanganan terhadap infeksi, penemuan teknik biopsi endomiokard untuk mendeteksi reaksi penolakan akut dan penemuan obat imunosupresif, angka harapan hidup telah mencapai sekitar $80 \%$ di tahun pertama, dan $70 \%$ di tahun ke lima. Saat ini lebih dari 66.000 transplantasi jantung dan 3047 transplantasi jantung-paru telah berhasil dilakukan pada 220 pusat jantung di seluruh dunia. Program transplantasi jantung di Pusat Jantung \& Diabetes Northrhine Westphalia Bad Oeynhausen berawal pada tanggal 13 Maret 1989, dan pada tahun yang sama sebanyak 39 transplantasi jantung telah dilakukan. Satu tahun kemudian, sejumlah 129 penderita gagal jantung kronik berhasil ditransplantasi. Angka ini melebihi jumlah total transplantasi jantung di Jerman saat itu. Pada tahun berikutnya, jumlah transplantasi meningkat

5 Ibid, h. 15.

HIKMAH, Vol. XIV, No. 2, $2018 \sim 109$ 
menjadi 148, dalam arti hampir 3 kali transplantasi jantung per minggu dan jumlah ini telah menembus nasional. Saat ini, program transplantasi jantung di Bad Oeynhausen termasuk salah satu pusat transplantasi jantung tersibuk di dunia. ${ }^{6}$

Selain tranplantasi jantung, transplantasi organ lain juga telah dilakukan, yakni transplantasi liver, kornea, ginjal, dan rahim. Selama bertahun-tahun, virus hepatitis $C$ di berbagai belahan dunia ini telah menjadi momok menakutkan, karena tak jarang menjadi penyebab kematian. Berbagai pengobatan dan terapi dilakukan untuk menyembuhkan penyakit ini, salah satunya adalah transplantasi liver. Prosedur sudah kerap dilakukan di banyak negara maju termasuk Singapura. Jenis transplantasi yang paling dikenal adalah tranplantasi kadaver, yakni mengambil liver sehat dari orang yang sudah meninggal. Adapun prosedur transplantasi liver dari donor hidup pertama kali dilakukan di Brazil pada 1987 namun membawa kegagalan. Baru pada 1989 bisa berjalan sukses pada transplantasi yang dilakukan di Brisbane, Australia. ${ }^{7}$

Masyarakat Indonesia yang pernah menjalani transplantasi liver adalah intelektual muslim Nurcholish Madjid (Cak Nur), ia menjalani transplantasi hati di Pusat Transplantasi Organ dan Cuci Darah, Rumah Sakit Rakyat Taiping, Humen, Provinsi Guangdong, 23 Juli 2004. Operasi itu memakan waktu delapan jam dengan melibatkan 12 tenaga medis. Usai operasi, kondisi Cak Nur menggembirakan. Sehari setelah operasi, selang di mulut sudah bisa dilepas. Setelah itu, berturut-turut alat bantu lainnya juga dicabut dari tubuhnya. Pada pekan ketiga, Cak Nur bahkan sudah bisa sedikit berjalan dan sudah bisa bercanda dengan putrinya. ${ }^{8}$ Transplantasi hati juga pernah dijalani oleh Dahlan Iskan, Pengasuh pesantren mahasiswa AnNur Surabaya dan ia berhasil menjalani transplatasi tersebut dengan baik bahkan kondisi kesehatannya bertambah baik

6 http://www.kalbe.co.id/files/cdk/files/147_11PengalamanKlinisTransplantasiJantung.pdf /147_11PengalamanKlinisTransplantasiJantung.html\#2. didownload tanggal 17 April 2017.

7 http://www.sinarharapan.co.id/index.html. Download tanggal 17 April 2017.

8 http://swaramuslim.net/weblog.php?id=C0_16_1. Download tanggal 17 April 2017. 
pasca transplantasi. ${ }^{9}$

Secara umum menurut M. F. A. Woodruf ada tiga tipe transplantasi organ, yaitu: ${ }^{10}$

a. Autotransplantasi, yaitu transplantasi organ yang menggunakan bagian-bagian tubuh atau organ dari tubuh si pasien itu sendiri. Dalam hal ini transplantasi kulit, tulang rawan, otot, dan tulang merupakan praktik-praktik yang sering dilakukan dalam bedah ortopedis.

b. Homotransplantasi (Allotransplantasi), yaitu transplantasi organ pada spesies yang sama, misalnya tranplantasi organ manusia kepada manusia.

c. Heterotransplantasi, yaitu transplantasi organ pada spesies yang berbeda, misalnya transplantasi dari hewan kepada manusia, atau antara hewan yang satu dengan hewan lainnya dari spesies yang sama.

Di antara ketiga tipe transplantasi tersebut yang paling sedikit resikonya adalah autotransplantasi, yakni bila organ atau jaringan pengganti berasal dari tubuh sendiri. Karen hal ini tidak akan menimbulkan rejeksi. Sebaliknya, organ atau jaringan yang berasal dari orang lain (kecuali saudara kembar satu telur) sering menimbulkan reaksi penolakan yang mungkin mengakibakan berbagai komplikasi. Bagaimana cara untuk mengatasi reaksi penolakan serta metode yang tepat untuk menguji kecocokan antara donor dan penerima, merupakan dua hal dalam bidang transplantasi yang sampai kini terus dikaji oleh para ahli. ${ }^{11}$

Tipe transplantasi jika dilihat dari segi pendonornya, menurut Said Agil Husin al-Munawar ada tiga tipe, yaitu: ${ }^{12}$

a. Donor dalam keadaan hidup sehat dan menjalani seleksi

9 http://www.korwilpdip.org/modules/smartsection/category.php?categoryid=7.Download tanggal 17 April 2017.

10 Abul Fadl. Kloning.., h. 16.

11 http://www.republika.co.id/suplemen/default.asp?mid=2. Download tanggal 17 April 2017.

12 Said Agil Husin Al-Munawar. Hukum Islam dan Pluralitas Sosial (Jakarta: Penamadani, 2004), h 77 .

HIKMAH, Vol. XIV, No. 2, $2018 \sim 111$ 
yang cukup ketat serta menyeluruh (general check up).

b. Donor sedang dalam keadaan hidup koma atau menurut pengalaman medis, orang itu diduga kuat akan segera meninggal.

c. Donor dalam keadaan sudah meninggal.

\section{Pemahaman Hadis}

\section{a. Teks Hadis}

Sebagaimana yang telah dikemukakan, bahwa transplantasi organ yang dipraktekkan sekarang belum pernah terjadi pada masa Rasulullah, sehingga tidak ada hadis yang secara spesifik membahas tentang transplantasi tersebut. Hanya saja pada masa nabi telah ada sahabat yang mengganti organ tubuhnya yang rusak dengan sesuatu yang lain. Hadis tersebut adalah:

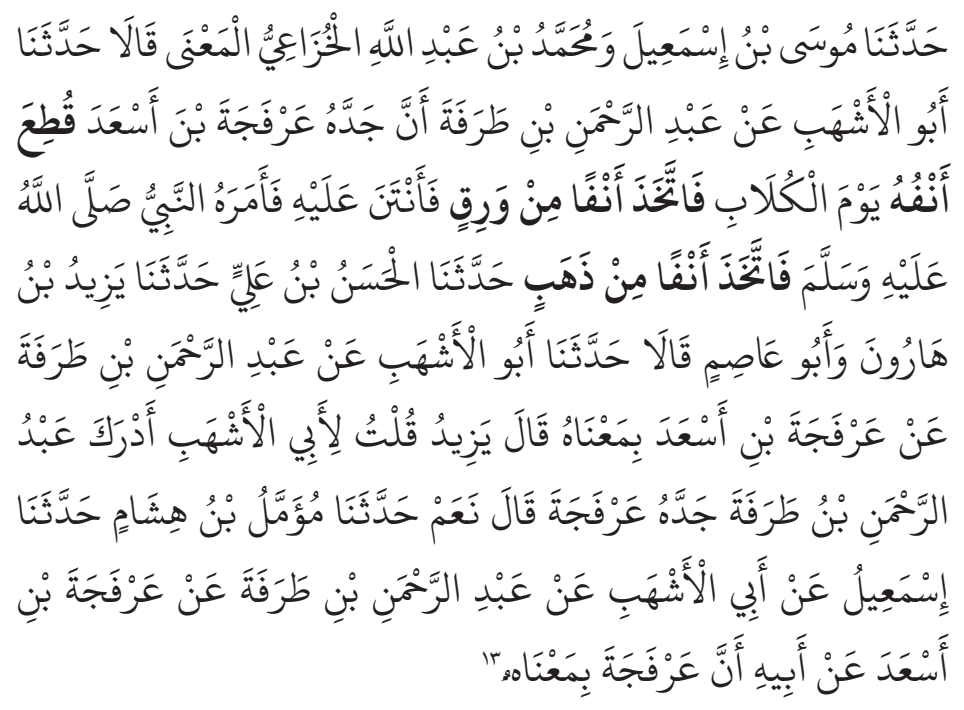

"Berkata kepada kami Musa ibn Isma'il dan Muhammad ibn Abdillah al-Khuza'i al-Ma'na, berkata al-Asyhab dari Abd

13 Sunan Abi Dawud, no. 3696 Kitab al-Khatam, Bab Ma Ja'a Fi Rabthi al-Asnan Wa al-Dzahab dalam CD ROM Mausu'ah al-Hadis al-Syarif al-Kutub al-Tis'ah, 
al-Rahman ibn Tharafah bahwa kakeknya yang bernama 'Arfajah ibn As'ad hidungnya terpotong (karena tertimpa sesuatu) pada hari Kulab, kemudian ia mengantinya dengan hidung palsu dari perak, setelah beberapa hari hidung perak tersebut mengeluarkan bau tidak sedap, maka Rasulullah SAW menyuruhnya untuk mengganti denga hidung palsu dari emas. Dalam hadis ini berkata pula Hasan ibn Ali berkata Yazid ibn Harun dan Abu 'Ashim berkata Abu al-Asyhab dari Abd al-Rahman ibn Tharafah dari Arfajah ibn As'ad, Yazid berkata saya telah bertanya kepada Abu al-Asyhab apakah benar Abd al-Rahman ibn Tharafah mempunyai kakek yang bernama Arfajah, ia menjawab: benar, berkata pula Muammal ibn Hisyam berkata Ismail dari Abd al-Rahman ibn Tharafah dari Arfajah ibn As'ad dari ayahnya bahwa Arfajah benar telah melakukan itu."

Hadis di atas menerangkan tentang 'Arfajah, seorang sahabat Nabi SAW yang hidungnya terpotong dalam suatu pertempuran dan diganti dengan hidung palsu dari perak. Hidung palsu dari perak tersebut beberapa waktu kemudian menimbulkan bau yang tidak sedap, sehingga ia meminta nasihat Nabi SAW dan beliau menganjurkannya agar mengganti hidung palsu dari perak tersebut dengan hidung palsu lain dari emas.

\section{b. Kritik Historis (Otentisitas)}

Sejauh penelitian yang penulis lakukan, bahwa para perawi dalam hadis tersebut hampir keseluruhan berkualitas śiqah, serta masing-masing perawi bersambung hingga Nabi SAW, hanya ada satu perawi yang majhul yang dalam lafadz hadis tersebut "عرفة بن" yakni "عن أبيه "عرفجة" Dan hadis ini tidak memiliki syahid dan mutabi”, maka menurut Abu Isa bahwa hadis tersebut tergolong hadis hasan gharib.

\section{c. Kajian Linguistik}

Dalam hadis tersebut disebutkan bahwa Arfajah ibn 
As'ad قطع أنفه yang bermakna "hidungnya terpotong". Dalam bahasa arab قطع bermakna terpotong yang

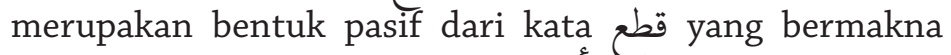
memotong. Selanjutnya فاتخذ أنفا من ورق yang bermakna "maka ia mengganti dengan hidung palsu dari perak". Secara linguistik hadis tersebut menceritakan bahwa Arfajah mengganti hidungnya yang terpotong dengan hidung palsu dari perak. Dari sini dapat dipahami bahwa ada penggantian organ tubuh yang rusak dengan sesuatu yang lain.

Tranplantasi yang mempunyai pengertian pemindahan organ tubuh yang masih mempunyai daya hidup sehat untuk menggantikan organ tubuh yang tidak sehat dan tidak berfungsi lagi dengan baik. Hadis yang disebutkan di atas bisa dijadikan qiyas pada tranplantasi organ, meskipun penggantian organ dalam hadis tersebut tidak dengan organ yang lain, namun dengan menggunakan benda lain, yakni perak dan emas. Hal ini karena memang pada zaman nabi belum terdapat praktek transplantasi sebagaimana yang marak sekarang. Sehingga tidak ada hadis yang membahas secara eksplisit mengenai transplantasi, dan para ulama pun membahas transplantasi ini dalam kajian ijtihadiyah, yakni dengan merujuk pada kedua sumber ajaran Islam, alQur'an dan Hadis.

\section{d. Kajian Tematis Komprehensif}

Hadis lain yang semakna dengan hadis tersebut adalah hadis yang diriwayatkan olah al-Tirmidzi (Kitab alLibas Min Rasulillah no. 1692), al-Nasa'i (Kitab al-Zinah no. 5070 dan 5071). Adapun hadis lain yang berkaitan dengan masalah ini adalah hadis yang menyatakan tentang perintah untuk berobat ketika seseorang menderita sakit, yaitu:

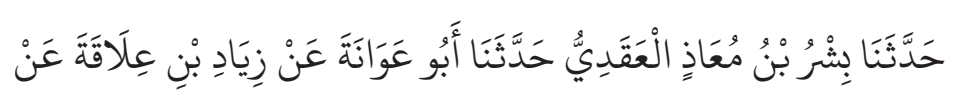




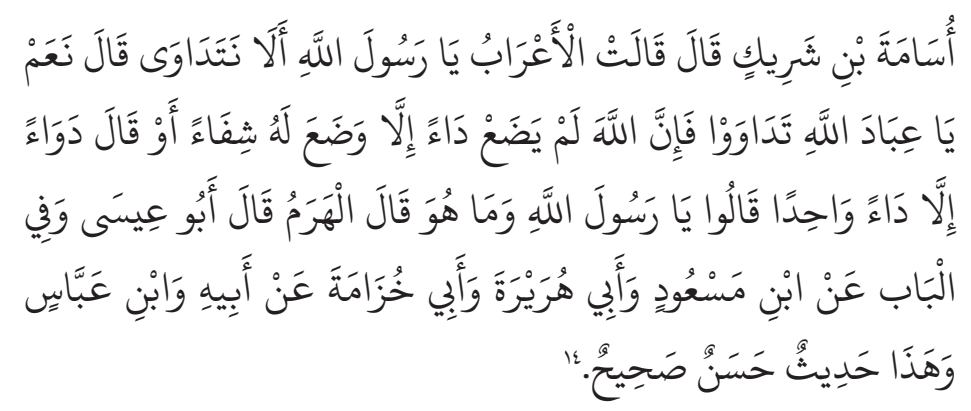

Artinya: "Diceritakan dari Bisyr ibn Mu'adz al-Aqadiyyu, diceritakan Abu 'Awanah dari Ziyad ibn 'Ilaqah dari Usamah ibn Syarik berkata: al-A'rab berkata: wahai Rasulullah apakah kita harus berobat, Rasulullah menjawab: benar, wahai hamba Allah berobatlah kalian karena sesungguhnya Allah tidak memberikan suatu penyakit, kecuali memberinya obat penyembuhnya kecuali satu penyakit, yaitu sakit tua, Abu Isa berkata bab ini diceritakan pula dari Ibnu Mas'ud, Abi Hurairah, Abi Khuzamah, dari ayahnya, dan Ibnu Abbas, dan ini adalah hadis hasan şahịh".

Hadis tersebut menganjurkan manusia untuk berobat jika ia sakit, karena Allah memberikan penyakit, dan tentu penyakit tersebut ada obatnya, kecuali sakit tua. Karena itu penyakit yang sangat ganas, seperti kanker dan AIDS yang telah banyak membawa korban manusia di seluruh dunia, terutama di dunia Barat, yang hingga kini masih belum ditemukan obatnya, maka pada suatu waktu akan ditemukan obatnya pula. ${ }^{15}$ Dan trannsplantasi organ tubuh ini merupakan salah satu jenis pengobatan modern yang mempunyai peranan baik dalam menyelamatkan jiwa manusia, karena pada umumnya berkaitan dengan organ tubuh yang vital.

\section{e. Kajian Konfirmatif}

Firman Allah dalam Q.S. al-Maidah ayat 32 yang

14 Sunan al-Tirmidzi, no 1961, Kitab al-Thib 'an Rasulillah Bab Maa Ja'a Fi al-Dawa' Wa al-Haq Alaih, dalam CD ROM Mausu'ah al-Hadis al-Syarif al-Kutub al-Tis'ah.

15 Masjfuk Zuhdi. Masail Fiqhiyah Kapita Selekta Hukum Islam, (Jakarta: PT Toko Gunung Agung, 1997), h. 91. 
artinya:

"Oleh karena itu kami menetapkan atas Bani Israil, bahwa barang siapa membunuh satu jiwa, bukan karena jiwa yang lain, atau bukan karena membuat kerusakan di muka bumi, maka seakan-akan dia telah membunuh seluruh manusia. Dan barang siapa memelihara kehidupan seorang manusia, maka seolah-olah dia telah memelihara kehidupan manusia seluruhnya. Dan sesungguhnya telah datang kepada mereka para rasul Kami dengan keterangan-keterangan yang jelas, kemudian sesungguhnya banyak di antara mereka sesudah itu melampaui batas di muka bumi"

Menurut M. Quraish Shihab, ayat tersebut mempersamakan antara pembunuhan terhadap seorang manusia yang tidak berdosa dengan membunuh sesama manusia, dan yang menyelamatkannya sama dengan menyelamatkan semua manusia. Peraturan baik apapun yang ditetapkan oleh manusia atau oleh Allah, pada hakikatnya adalah untuk kemaslahatan masyarakat manusia. ${ }^{16}$

Lebih lanjut ia menjelaskan kata "menghidupkan" pada ayat tersebut bukan saja yang berarti "memelihara kehidupan", tetapi juga dapat mencakup upaya "memperpanjang harapan hidup" dengan cara apa pun yang tidak melanggar hukum. Secara kontekstual ayat tersebut menngisyaratkan, bahwa transplantasi organ yang menjadi salah satu teknik pengobatan dan bisa memelihara kehidupan serta membawa kemaslahatan, maka hal ini dibolehkan dalam al-Qur'an.

\section{f. Analisa Realitas Historis}

Rasulullah SAW menganjurkan umatnya untuk selalu menjaga kesehatan. Ketika ada seorang sahabat sedang menderita sakit, maka Rasulullah menganjurkan untuk segera mengobatinya. Berbagai jenis pengobatan telah

16 M. Quraish Shihab. Tafsir al-Misbah Pesan, Kesan, dan Keserasian Al-Qur'an. Volume III (Jakarta: Lentera Hati, 2002), h.81. 
berkembang pada masa itu, namun semua masih pada taraf pengobatan alamiah, artinya belum adanya alat kedokteran yang canggih sebagaimana yang ada pada dewasa ini. Di antara jenis pengobatan pada masa nabi ialah:

\section{1) Pengobatan dengan madu}

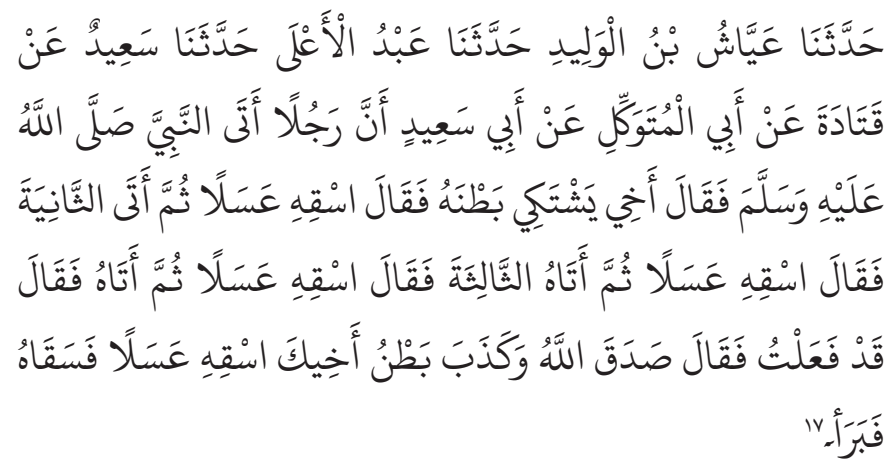

Artinya: "Berkata kepada kami 'Ayyas ibn Walid, berkata kepada kami Abd al-A'la berkata kepada kami Sa’id dari Qatadah dariAbial-Mutawakkil dariAbiSa'id berkata:ada seorang laki-laki datang menemui Nabi SAW lalu berkata: saudaraku perutnya terasa mual-mual. Rasulullah SAW bersabda: minumilah madu! Setelah lelaki itu memberikan madu kepada saudaranya, dan datang lagi kepada Rasulullah SAW dan menyatakan: aku telah memberinya madu tapi perutnya bertambah mulas, kejadia ini berulang hingga tiga kali. Kemudian Rasulullah SAW bersabda: minumilah madu! lelaki tersebut masih mengatakan lagi: aku telah benar-benar memberinya madu, tetapi perutnya bertambah mulas. Maka Rasulullah SAW bersabda: Maha Benar Allah yang telah berfirman: dari perut lebah itu kaluar minuman (madu) yang bermacammacam warnanya, di dalam obat itu terdapat obat yang menyembuhkan bagi manusia. oleh karena itu mungkin ada yang tidak beres dengan dengan perut saudaramu itu. Akhirnya Rasulullah SAW sendiri yang memberikan madu

17 Şahīh al-Bukhari no. 5252, Kitab al-Thib Bab al-Dawa' bi al-'Asal, dalam CD ROM Mausu'ah al-Hadis al-Syarif al-Kutub al-Tis'ah. 
dan sembuhlah saudara lelaki itu".

Pernyataan bahwa madu ini mengandung obat juga termaktub dalam QS. an-Nahl Ayat 69 yang artinya adalah "Dari perut lebah itu keluar minuman (madu) yang bermacam-macam warnanya, di dalamnya terdapat obat yang menyembuhkan bagi manusia. Sesungguhnya pada yang demikian itu benar-benar terdapat tanda (kebesaran Allah) bagi orang-orang yang memikirkan" Pengobatan dengan madu telah dibuktikan dalam beberapa penelitian. Salah satu peneliti adalah Peter Nolan seorang ahli riset biokimia dari The University of Waikato - New Zealan, ia mempunyai pengalaman, kejadian yang dialami seorang remaja Inggris berusia 20 tahun yang luka di tangannya tidak mempan diobati oleh berbagai jenis antibiotik. Kemudian diobati dengan madu, setelah pengobatan dengan madu berjalan selama satu bulan, ternyata luka di tangan remaja tersebut benar-benar sembuh dan tangannya dapat berfungsi kembali.

Madu ternyata dapat menumpas spesies microbial yang resistance terhadap antibiotik buatan manusia. Penggunaan madu sebagai antibiotik juga memiliki beberapa keunggulan antara lain :

a) Pengobatan dengan madu tidak menimbulkan inflamasi

b) Madu menyebabkan rasa sakit berkurang

c) Madu membersihkan infeksi

d) Madu menghilangkan bau pada luka

e) Penyembuhan berjalan cepat tanpa menimbulkan bekas luka

f) Madu bersifat antimicrobial yang dapat mencegah microba tumbuh

g) Tidak menimbulkan rasa sakit pada saat penggantian pembalut karena tidak lengket

h) Mempunyai stimulatory effect yang mempercepat 
tumbuhnya jaringan tubuh kembali. ${ }^{18}$

\section{2) Pengobatan dengan jinten hitam}

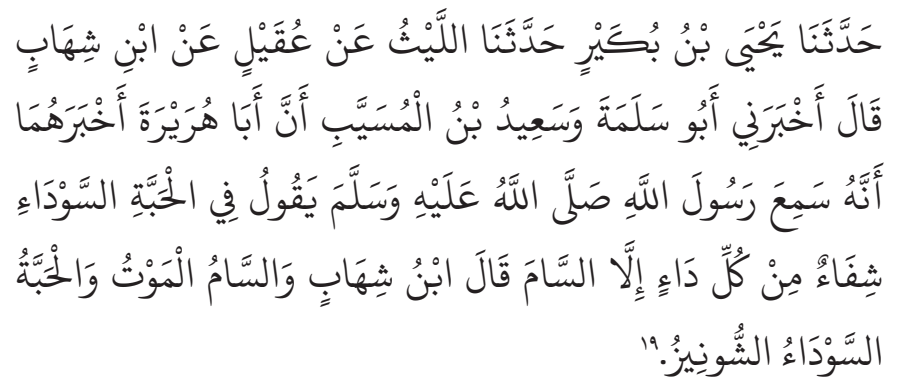

"Berkata kepada kami Yahya ibn Bukair, berkata kepada kami al-Laits dari 'Uqail dari Ibnu Syihab berkata, berkata kepada saya Abu Salamah dan Sa'id ibn al-Musayyab bahwasannya Abu Hurairah berkata kepada keduanya bahwasanya ia mendengar Rasulullah SAW bersabda: sesungguhnya pada jinten hitam itu terdapat obat segala macam penyakit kecuali racun, Ibnu Syihab berkata dan racun itu adalah mati, dan jinten hitam itu adalah syuniz (sejenis jinten h itam)".

Pengobatan dengan jinten hitam ini sering dilakukan pada masa Rasulullah. Nama lain dari Habbatus Sauda' adalah Nigella Sativa, al-Karawiyyah as-Sauda', al-Kamoun al-Aswad, asy-Syuniz, black cumin, kerosene, coal oil, carazna, yang dalam bahasa Indonesia disebut dengan jinten hitam. Menurut beberapa hasil penelitian, Habbatus Sauda`memiliki berbagai macam khasiat, di antaranya adalah:

a) Menguatkan immunity system pada diri manusia.

b) Melawan dan menghancurkan sel-sel kanker/ tumor.

c) Mengobati reumatik, peradangan serta infeksi.

18 http://rumahmadu.com/2017/02/madu-bisa-jadi-obat-yang-lebih-baik.html. Download tanggal 05 Juni 2017.

19 Şahìh al-Bukhari no. 5256, Kitab al-Thib Bab al-Habbah al-Sauda', dalam CD ROM Mausu'ah al-Hadis al-Syarif al-Kutub al-Tis'ah. 
d) Menghentikan dan menyembuhkan penyakit pilek, pusing, dan batuk.

e) Membunuh cacing-cacing parasit.

f) Minyaknya bermanfaat untuk menyembuhkan gigitan ular, sengatan laba-laba juga bengkak di dubur dan tahi lalat.

g) Menghilangkan sesak nafas.

h) Melancarkan haidh yang tersendat.

i) Jika diminum, biji ini akan melancarkan kencing, haidh dan ASI.

j) Menghilangkan kusta (lepra).

k) Jika disedot melalui hidung akan bermanfaat menghentikan air yang keluar pada mata. ${ }^{20}$

\section{3) Pengobatan dengan berbekam (canthuk).}

Berbekam termasuk pengobatan yang diajarkan Rasulullah SAW, bahkan Rasulullah SAW pernah melakukan bekam dan memberikan upah kepada tukang bekam.

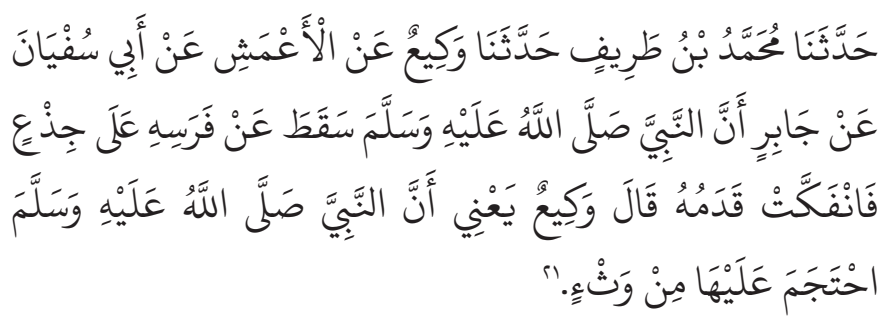

Artinya: "Berkata kepada kami Muhammad ibn Tharif, berkata kepada kami Waki' dari al-A'masy dari Abi Sufyan dari Jabir bahwasannya Rasulullah SAW terjatuh dari tempat tidurnya, kemudian retaklah kakinya, Waki' berkata bahwasannya Rasulullah SAW kemudian berbekam untuk mengurangi sakitnya".

20 http://www.ikhwan-interaktif.com/islam/?pilih=news\&aksi=pesan\&id=1948. Download tanggal 05 Juni 2017.

21 Sunan Ibnu Majah no. 3476, Kitab al-Thib Bab Maudhiu al-Hijamah, dalam CD ROM Mausu'ah al-Hadis al-Syarif al-Kutub al-Tis'ah. 
Pengobatan dengan berbekam ini dimulai sejak zaman Mesir Kuno, bahkan kemudian berkembang di banyak negara (termasuk Cina), dan kini bekam ini juga dipraktikkan di Indonesia. Terapi yang dalam bahasa Arab disebut hijamah ini telah disesuaikan dengan sunah Nabi Muhammad. Tak heran, para terapis umumnya berasal dari pondok-pondok pesantren. ${ }^{22}$

4) Pengobatan dengan air zamzam

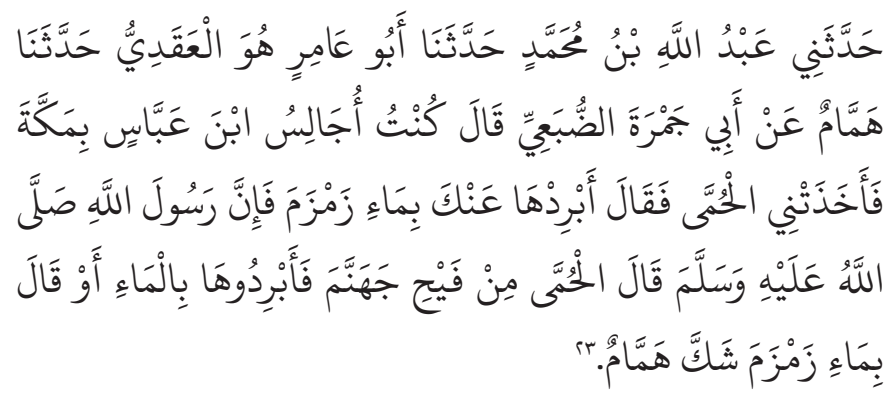

Artinya:"Berkata Abdullah ibn Muhammad, berkata Abu 'Amir yaitu al-Aqadi, berkata Hammam dari Abi Jamrah al-Dhaba'i berkata: ketika saya sedang duduk dengan Ibnu Abbas di Makkah kemudian saya menderita penyakit panas, maka ia berkata: dinginkanlah dengan air zamzam karena sesungguhnya Rasulullah SAW bersabda: sakit panas itu tanda panas api neraka, maka dinginkanlah dengan air (air zamzam), namun Hammam ragu".

Ibnul Qayyim rahimahullah berkata: "Aku sendiri dan juga yang lainnya pernah mempraktekkan upaya penyembuhan dengan air zamzam terhadap beberapa penyakit, dan hasilnya sangat menakjubkan, aku berhasil mengobati berbagai macam penyakit dan aku pun sembuh atas izin Allah". ${ }^{24}$

Selain dengan cara pengobatan di atas, Rasulullah

22 http://www.indospiritual.com/index.php. Download tanggal 05 Juni 2017.

23 Şahịh al-Bukhari No. 3021, Kitab Bad'u al-Khalqi Bab Shifatu al-Nar wa Annaha Makhluqatun. Dalam CD ROM Mausu'ah al-Hadis al-Syarif al-Kutub al-Tis'ah.

24 http://www.almanhaj.or.id/. Download tanggal 05 Juni 2017.

HIKMAH, Vol. XIV, No. 2, $2018 \sim 121$ 
SAW juga menganjurkan agar seseorang yang menderita sakit itu mendekatkan diri kepada Allah dengan memperbanyak salat, karena sesungguhnya dalam salat itu terdapat obat, yang didasarkan atas dua sebab, (1) Salat adalah sebuah ibadah, (2) secara psikis salat dapat mengalihkan perhatian dari rasa sakit dan meminimalisasi keluhannya. ${ }^{25}$ Para pakar kedokteranpun juga menyatakan bahwa kekuatan psikis seorang pasien akan sangat membantu terhadap kesembuhannnya. Mereka mengerahkan segala usaha untuk memompa kekuatan tubuh, mengupayakannya dengan mengonsumsi nutrisi psikis yang dapat mengeksplorasi kekuatan dan dapat melapangkan dada mereka sehingga penyakitnya segera sembuh.

Seiring dengan perkembangan zaman yang ditandai dengan kemajuan ilmu pengetahuan dan teknologi yang telah diaplikasikan dalam berbagai bidang termasuk bidang kedokteran, maka muncul penemuan-penemuan baru teknik pengobatan yang lebih canggih dan diyakini mempunyai banyak manfaat terhadap kelangsungan hidup manusia. Di antaranya adalah dengan transplantasi organ tubuh yang belum pernah dipraktekkan pada masa Rasulullah SAW. Para fukaha kontemporer telah mempertimbangkan permasalahan transplantasi ini dan memberikan pedoman fiqhiyyah tertentu yang didasarkan pada deduksi ajaran-ajaran dasar dua sumber hukum Islam, yaitu al-Qur'an dan hadis. Karena transplantasi organ merupakan kajian fiqhiyyah kontemporer, maka terjadi perbedaan pendapat dalam menentukan hukum transplantasi tersebut.

Menurut M. Quraish Shihab persoalan transplantasi ini, baik dari donor hidup maupun donor yang telah meninggal dunia ada beberapa

25 Abdul Basith Muhammad Sayyid. Rasulullah Sang Dokter. Terj. M. Masnur Hamzah, M. Habiburrahim (Solo: Tiga Serangkai, 2004), h. 3. 
prinsip dan kesepakatan dalam bidang hukum agama yang berkaitan dan dapat membantu menemukan pandangan Islam dalam persoalan dimaksud. Prinsipprinsip dimaksud antara lain adalah: ${ }^{26}$

a) Agama Islam bertujuan memelihara agama, jiwa, akal, kesehatan, dan harta benda umat manusia.

b) Anggota badan dan jiwa manusia merupakan milik Allah yang dianugerahkan-Nya untuk dimanfaatkan, bukan untuk disalahgunakan atau diperjualbelikan.

c) Penghormatan dan hak-hak asasi yang dianugerahkan-Nya mencakup seluruh manusia, tanpa membedakan ras atau agama.

d) Terlarang merendahkan derajat manusia, baik yang hidup, maupun yang telah wafat.

e) Jika bertentangan kepentingan antara orang yang hidup dan orang yang telah wafat, maka dahulukanlah kepentingan orang yang hidup.

Dari prinsip-prinsip ini banyak ulama kontemporer menetapkan bahwa transplantasi dapat dibenarkan selama tidak diperjualbelikan, dan selama kehormatan manusia yang hidup maupun yang mati terjaga sepenuhnya. Salah satu jaminan tidak adanya pelecehan adalah izin dan pihak keluarga. Alasan penolakan yang sering terdengar dari kalangan orang kebanyakan (awam) bahwa setelah si penerima donor sehat, ia mungkin dapat menyalahgunakan kesehatannya, dan ini dapat mengakibatkan dosa, terutama bagi „pemilik“ organ (jenazah), atau orang yang mengizinkan. Alasan ini, pada hakikatnya tidak sepenuhnya dapat diterima. Kemurahan dan keadilan Tuhan mengantar-Nya untuk tidak menuntut pertanggungjawaban dari

26 http://media.isnet.org/islam/Quraish/Wawasan/index.html. Download tanggal 18 April 2017. 
seseorang terhadap sesuatu yang tidak dikerjakannya secara sadar, karena hakikat manusia bukan organ dan jasmaninya.

Adapun pandangan-pandangan para ulama adalah sebagai berikut:

\section{a. Pendapat-Pendapat yang Melarang Transplantasi Organ Tubuh}

Di antara ulama yang menentang terhadap transplantasi organ adalah Mufti Muhammad Syafi dari Pakistan dan Dr. Abd. Al-Salam dari Mesir. Menurut Mufti Syafi bahwa transplantasi organ itu tidak diperbolehkan berdasarkan atas tiga prinsip: ${ }^{27}$

1) Kesucian hidup atau tubuh manusia

Hal ini didasarkan pada ayat al-Qur'an surat alNisa: 29, al-Baqarah ayat: 195, yang menjelaskan adanya larangan bunuh diri. Adapun hadis yang mendukung adalah:

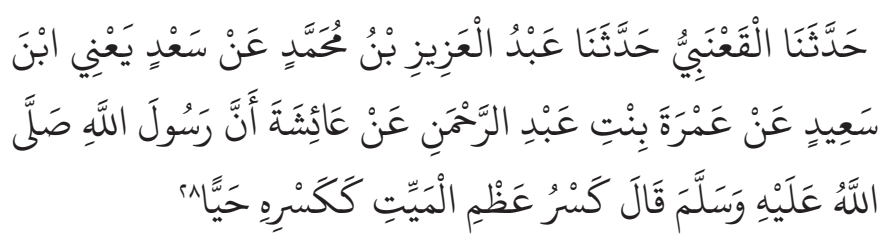

Berdasarkan hadis di atas, dapat disimpulkan bahwa merusak jasad mayat itu dilarang, maka hal ini membawa implikasi dilarangnya membedah tubuh mayat untuk diambil organnya dan ditransplantasikan kepada orang lain.

2) Tubuh manusia sebagai amanah

Hal ini didasrkan pada al-Qur'an Surat al-Isra: 70, dan al-Balad: 8-9. Dari kedua ayat tersebut dapat

27 Abul Fadl. Kloning.., h. 82.

28 Sunan Abi Daud, no. 2792. kitab al-Janaiz, dalam CD ROM Mausu'ah al-Hadis al-Syarif alKutub al-Tis'ah. 
dipahami bahwa manusia tidak memiliki hak untuk mendonorkan satu bagian pun dari tubuhnya karena organ-organ tersebut pada dasarnya bukan miliknya, melainkan amanah yang dititipkan kepadanya.

3) Praktik transplantasi bisa disamakan dengan memperlakukan tubuh manusia sebagai benda material.

Pendapat ini didasarkan pada hadis bahwa Nabi SAW bersabda bahwa Allah SWT mencela atu mengutuk orang yang menggabungkan rambut seorang wanita dengan rambut orang lain untuk menjadikannya tampak panjang, dan dia juga mengutuk wanita yang rambutnya dipotong untuk tujuan itu.

\section{b. Pendapat-Pendapat yang Membolehkan Transplantasi Organ Tubuh}

Para ulama yang mendukung pembolehan transplantasi organ mereka berpendapat bahwa transplantasi organ harus dipahami sebagai bentuk layanan altruistik bagi sesama muslim. Tindakan transplantasi ini dapat membawa maslahah bagi kesejahteraan publik. Namun kebolehan donor organ tersebut tetap didasarkan pada syarat-syarat tertentu, yaitu:

1) Tidak menimbulkan bahaya bagi orang yang diambil organnya (pendonor).

2) Terdapat dugaan kuat atas manfaat dari organ tersebut bagi penggunanya (resipien). ${ }^{29}$

3) Ada persetujuan dari pemilik organ asli (ahli warisnya).

4) penerima organ sudah tahu persis segala implikasi pencangkokan (informed consent).

Di antara lembaga-lembaga pemberi fatwa di dunia Muslim, pandangan yang dominan adalah pandangan

29 Muhammad Manshur, Fikih Orang Sakit, terj. Iman Sulaiman (Jakarta: Pustaka al-Kautsar, 2003), h. 202. 
yang mendukung bolehnya pencangkokan organ. Di antara lembaga semacam itu yang mendukung pencangkokan organ adalah Akademi Fikih Islam (lembaga di bawah Liga Muslim Se-Dunia, yang berpusat di Arab Saudi) pada fatwa-fatwanya pada tahun 1985 dan 1988, Akademi Fikih Islam India (1989), dan Dar al-Ifta' (lembaga otonom semcam MUI, di bawah Departemen Agama, Mesir, yang biasanya diketuai oleh ulama dari Universitas alAzhar). Pencangkokan yang diperbolehkan mencakup autotransplantasi, allotransplantasi (homotransplantasi), dan heterotransplantasi. Meski demikian, diperbolehkannya pencangkokan organ ini selalu diikuti syarat-syarat sebagaimana disebutkan di atas. ${ }^{30}$

Menurut Said Agil Husin al-Munawar bahwa transplantasi organ tubuh seseorang yang hidup dan sehat kepada orang lain pada hakikatnya tidak boleh, tetapi manakala hal itu menjadi satu-satunya jalan untuk menyelamatkan orang yang memang amat dicintainya, dan orang itu secara medis dijamin tidak menghadapi resiko yang lebih buruk, maka dibolehkan asal ada kerelaan dari orang yang mendonorkan organ tubuhnya itu. prinsip yang dipegang adalah kaidah ushul fiqh لا ضرر ولا ضرار, yakni tidak merugikan diri sendiri dan tidak merugikan orang lain. Pengambilan organ tubuh manusia pada waktu si donor dalam keadaan hidup koma, juga tidak diizinkan oleh agama Islam, karena manusia berkewajiban menyembuhkan penyakitnya secara maksimal. Adapun pengambilan organ tubuh pada waktu si donor telah benarbenar meninggal dunia, maka dapat dibenarkan oleh sebagian ulama. Menurut Aam Amiruddin, transplantasi merpakan cara pengobatan yang diperbolehkan Islam. Menjadi pendonor hukumnya mubah bahkan bernilai ibadah kalau dilakukan dengan ikhlas asal tidak membinasakannnya. orang meninggal boleh dimanfaatkan organnya untuk pengobatan dengan catatan sebelum wafat

30 Abul Fadl. Kloning.., h 95-99. 
orang tersebut mengizinkannya. ${ }^{31}$

Menurut fatwa Majelis Ulama Indonesia, bahwa kebolehan pencangkokan organ adalah dengan berbagai syarat, yaitu: (1) donor adalah orang yang telah meninggal dunia, (2) ada wasiat dari donor yang diketahui, (3) transplantasi harus dilakukan oleh ahli bedah yang berpengalaman. ${ }^{32}$ Menurut KH. Ma'ruf Amin, bahwa untuk transplantasi organnya diperbolehkan tapi yang tidak diperbolehkan atau haram adalah jual-beli organnya. Karena sebenarnya manusia tidak berhak "memberikan" organ kita itu. Tapi manusia memanfaatkan organ yang diberikan oleh Tuhan kepadanya. Tetapi jika ada yang memerlukan organ orang lain dan diatur oleh negara (pemerintah) dalam hal ini tidak dijual belikan maka diperbolehkan. Sepanjang tidak membahayakan pendonor dan resipien, boleh memberikan, namun tidak boleh adanya komersialisasi. Karena manusia hanya diamanati oleh Sang Pencipta untuk menjaga anugerah yang telah diberikan oleh-Nya. ${ }^{33}$

\section{Kritik Praksis (Lokal, Temporal, Universal)}

Transplantasi organ sudah tidak asing lagi di negaranegara maju yang telah memanfatkan dan mempunyai teknologi canggih, seperti di Australia, China dan Singapura. Bahkan di negara berkembang seperti di Indonesia sudah sering dilakukan, misalnya di RSU dr. Soetomo Surabaya. Transplantasi organ yang sering dilakukan di RSU dr Soetomo adalah transplantasi ginjal. Kebanyakan donor untuk transplantasi ginjal adalah donor hidup dan diambilkan dari keluarga. Untuk transplantasi organ lain, misalnya liver, masih belum bisa dilakukan. Meskipun pada rumah sakit tersebut sudah ada timnya untuk melakukan operasi transplantasi liver, namun masyarakat lebih suka memilih ke luar negeri. Sebab

31 Aam Amiruddin. Bedah Masalah Kontemporer II Tanya-Jawab Ibadah \& Muamalah, (Bandung: Khazanah Intelektual, 2005), h. 276.

32 Said Agil, Hukum..., h. 98-99.

33 http//erabaru.or.id/k-20. htm. Download tanggal 18 April 2017. 
lain adalah sulitnya mendapatkan donor liver tersebut. ${ }^{34}$

Dr. Tommy Sunartomo Sp.An (anggota tim transplantasi RSU dr Soetomo) menyatakan, secara medis, seseorang yang masih hidup dan mendonorkan organ tubuhnya, misalnya ginjal, tidak akan mempengaruhi kesehatannya. Menurut dia, selama ini, banyak orang yang hidup, meski hanya dengan satu ginjal. Namun permasalahannya, ada masyarakat yang memandang donor organ tubuh dengan pemahaman lain, apalagi dari sisi agama.

Melihat fenomena yang ada, maka menurut hemat penulis bahwa transplantasi organ ini harus dilihat dari segi manfaat dan madharatnya. Dari segi manfaat, memang transplantasi sangat membantu resipien untuk menyelamatkan jiwanya, dan bahwasannya transplantasi ini merupakan tindakan altruisme (al-itsar), yakni mendahulukan kepentingan orang lain, dan hal ini sangat dipuji oleh agama. Namun kita juga harus melihat pada aspek madharatnya, seperti tidak cocoknya organ donor dengan resipien, hal ini akan menimbulkan adanya penolakan (rejeksi) pada tubuh resipien itu yang mungkin mengakibakan berbagai komplikasi. Untuk mengatasi reaksi penolakan serta metode yang tepat untuk menguji kecocokan antara donor dan penerima, maka dua hal ini merupakan hal yang paling urgen dalam bidang transplantasi yang sampai kini terus dikaji oleh para ahli.

Hal lain yang perlu diperhatikan, yakni dengan transplantasi organ dari non muslim. Mengenai hal ini sebagin ulama termasuk al-Dlahiriyah memandang orang kafir (nonmuslim) secara najis aini, baik ketika masih hidup atau sudah meninggal dunia. Pendapat ini didasarkan pada Q.s al-Taubah: 28. Jadi, jasad orang kafir najis hukumnya, dan tidak boleh ditransplantasikan dan diberikan kepada orang lain. Selanjutnya pendapat yang membolehkan transplantasi organ dari nonmuslim adalah didasarkan pada adanya

34 http://www.jawapos.com/index.php?act=cetak\&id=28. download pada tanggal 18 April 2017. 
kebolehan seorang muslim menikahi wanita ahli kitab, hal ini mengindikasikan bahwa badan nonmuslim baik sewaktu masih hidup maupun sudah meninggal adalah suci. Dan bahwasannya najis yang dimaksudkan dalam al-Qur'an surat al-Taubah: 28 adalah najis maknawi.

\section{KESIMPULAN}

Transplantasi organ sebagai teknik pengobatan merupakan kemajuan dan temuan baru dalam dunia kedokteran modern. Transplantasi ini dalam tinjauan hukum Islam merupakan masalah kontemporer, dan tidak ada nash al-Qur'an dan hadis yang secara eksplisit menyebutkan tentang transplantasi tersebut. Sebagai konsekuensi, ulama kontemporer harus membahas masalah ini dengan mengkaji ayat-ayat al-Qur'an dan hadis yang terkait dengan hal tersebut, sehingga sangat wajar jika terjadi perbedaan pendapat dengan dalil-dalil yang mendukung argumentasi mereka masingmasing.

Ulama yang melarang adanya tranplantasi organ ini secara umum berpendapat bahwa; kesucian hidup atau tubuh manusia, tubuh manusia sebagai amanah, dan praktik transplantasi bisa disamakan dengan memperlakukan tubuh manusia sebagai benda material. Adapun ulama yang memperbolehkan transplantasi organ ini mereka berpendapat bahwa hal tersebut merupakan tindakan altruisme (al-itsar), yakni mendahulukan kepentingan orang lain, serta dapat membawa kesejahteraan publik.[] 


\section{DAFTAR PUSTAKA}

Al-Fanjari, Ahmad Syauqi. Nilai Kesehatan dalam Syariat Islam, Terj. Ahsin Wijaya dan Totok Jumantoro, Jakarta: Bumi Aksara, 2005.

Al-Munawar, Said Agil Husin. Hukum Islam dan Pluralitas Sosial, Jakarta: Penamadani, 2004.

Amiruddin, Aam. Bedah Masalah Kontemporer II Tanya-Jawab Ibadah \& Muamalah, Bandung: Khazanah Intelektual, 2005.

Ebrahim, Abu Fadl Mohsin. Kloning, Eutanasia, Transplantasi Organ, dan Eksperimen pada Hewan Telaah Fikih dan Bioetika Islam, Terj. Mujiburrohman, Jakarta: PT Serambi Ilmu Semesta, 2004.

Hasan, M. Ali. Masail Fiqhiyah al-Haditsah pada Masalah-Masalah Kontemporer Hukum Islam, Jakarta: PT. Raja Grafindo Persada, 1998.

Mahalli, Ahmad Mujab dan Hasbullah, Ahmad Rodli. Hadis-Hadis Muttafaq 'Alaih Bagian Munakahat \& Mu'amalat, Jakarta: Kencana, 2004.

Manshur, Muhammad. Fikih Orang Sakit, Terj. Iman Sulaiman, Jakarta: Pustaka al-Kautsar, 2003.

Munawir, Ahmad Warson, al-Munawwir Kamus Arab-Indonesia, Surabaya: Pustaka Progressif, 1997.

Rofiq, Ahmad. Fiqh Kontekstual dari Normatif ke Pemaknaan Sosial, Yogyakarta: Pustaka Pelajar, 2004.

Sayyid, Abdul Basith Muhammad. Rasulullah Sang Dokter. Terj. M. Masnur Hamzah, M. Habiburrahim, Solo: Tiga Serangkai, 2004.

Shihab, M. Quraish. Tafsir al-Misbah Pesan, Kesan, dan Keserasian Al-Qur'an. Volume III, Jakarta: Lentera Hati, 2002. 
Yasin, M. Nuaim. Fikih Kedokteran, Terj. Munirul Abidin, Jakarta: Pustaka al-Kautsar, 2001.

Zuhdi, Masjfuk. Masail Fiqhiyah Kapita Selekta Hukum Islam, Jakarta: PT Toko Gunung Agung, 1997.

CD. Mausu'ah al-Hadits al-Syarif, al-Kutub al-Tis'ah, versi 2.00.

http://www.republika.co.id/suplemen/default.asp?mid=2.

http://www.korwilpdip.org/modules/smartsection/category. php?categoryid $=7$.

http://media.isnet.org/islam/Quraish/Wawasan/index.html. 